\title{
JEAN-JACQUES ROUSSEAU E OS FUNDAMENTOS TEÓRICOS DO PODER POLÍTICO LEGÍTIMO
}

\author{
Arlei de Espíndola \\ Universidade Estadual do Oeste do Paraná - Unioeste
}

\begin{abstract}
The article is gone back to an analysis of Jean-Jacques' book entitled Rousseau "Of the social contract" that it occupies a central place in his political thought. It is looked for to rebuild the key concepts that seat the bases, to the author's eyes, of the legitimate political power and that they allow to think that Rousseau doesn't throw, at the end, the theoretical subsidies of the several totalitarian political regimes appeared after his time.

Keywords: social contract; general will; legitimacy of the power; freedom; equality.
\end{abstract}

Resumo: $O$ artigo é voltado para uma análise do livro de Jean-Jacques Rousseau intitulado "Do contrato social" que ocupa um lugar central em seu pensamento político. Busca-se reconstruir os conceitos chaves que assentam as bases, aos olhos do autor, do poder político legítimo e que permitem se pensar que Rousseau não lança, ao final, os subsídios teóricos dos diversos regimes políticos totalitários surgidos após sua época.

Palavras-Chave: contrato social; vontade geral; legitimidade do poder; liberdade; igualdade.

Rousseau propõe-se, em seu livro intitulado Do contrato social, a refletir sobre as vias para dar-se forma a uma comunidade política que tenha as suas bases assentadas num poder político passível de ser considerado legítimo. Sendo o poder desta natureza, a sociedade haveria de fazer-se bem ordenada e assegurar a cada homem os meios de desfrutar da maior felicidade 
possível, tendo os recursos necessários para aprimorar-se integralmente em seu nível mais elevado. ${ }^{1}$

A equação do problema colocado pelo texto e que decorre, na verdade, de um minucioso diagnóstico efetuado em obras anteriores, principalmente no Discurso sobre a desigualdade, passa pela realização de um pacto social legítimo. É esse pacto, com o qual os indivíduos alienam simultaneamente todos os seus direitos para o conjunto da comunidade de contratantes, que permitirá o advento da sociedade bem ordenada. Nessa ordem ideal, que floresce por meio deste artifício, os homens encontram a sorte de retomar a liberdade e a igualdade, vendo-se subordinados unicamente à lei cuja prescrição é feita por eles mesmos.

A obra de Rousseau colocada em pauta de discussão, embora seja breve, embora se caracterize por ser pequena, se considerarmos o volume da maioria dos tratados clássicos de semelhante gênero, se divide em 4 livros, apresentando, por assim dizer, duas ordens de problemas. A primeira ordem estaria centrada em buscar os fundamentos do poder político legítimo, encontrando-se disseminada em especial no livro 1, apesar de se estender claramente até o livro 2; a segunda procura refletir mais sobre o plano prático, sobre a esfera de funcionamento da máquina do Estado, delineando, sobretudo no livro 3 e 4, ainda que subsídios para isso sejam lançados também no livro 2 em seu ponto próximo de seu fechamento, a instância administrativa, a dimensão institucional em termos concretos, de semelhante engenho que nós mesmos estabelecemos.

Nossa meta, neste artigo, reside em deter-se na primeira ordem temática, buscando reconstruir, sem visar a exaustão, os conceitos chaves que servem de fundamento do poder que o filósofo genebrino aspira ver instituído. Objetivamos, com essa escrita, indicar que o autor não fornece, de um lado, os subsídios ideológicos utilizados pelos homens práticos que dão forma, mais tarde, aos diversos regimes políticos totalitários.

Esses princípios filosóficos, que retomaremos aqui de forma muito rápida, servem de fonte inspiradora, de outro lado, às críticas contundentes dirigidas a Rousseau, desde o século XIX, por vários pensadores e escritores sintonizados com a perspectiva política liberal. Teremos condições de mos-

\footnotetext{
1 "Como a sociedade pode ser organizada de maneira a assegurar nossa maior felicidade e aperfeiçoamento possível? É isso que o Contrat social tem por alvo mostrar" (DURKHEIM, Émile. "Le 'Contrat social' de Rousseau" Marcel Rivière et Cie, $1 \overline{953}$, p.147-148).
} 
trar, entretanto, que a posição teórica de Rousseau é dissonante em relação ao pensamento desses autores devido ao seu amor profundo à liberdade.

\section{I}

Ao dirigir-se o olhar para as páginas do livro I do Contrato social, e ler-se com o cuidado necessário os sucessivos capítulos pelos quais ele é constituído, tem-se a clara impressão de o texto ser mesmo um prolongamento do Discurso sobre a desigualdade. A diferença mais evidente está no fato de que o filósofo no primeiro escrito, ao contrário do trabalho de 1755 , não se limita a empreender uma negação quando aborda os problemas morais, políticos, e antropológicos.

Muitos duvidaram do caráter unitário e coerente da obra de Rousseau tomada em seu conjunto. Émile Faguet e Jules Lemaître, adeptos da leitura que indica para a presença da contradição e da dispersão, a título de exemplo, demonstraram dificuldades para conceber o Do contrato social como um livro que seria uma parte imprescindível do arcabouço geral da filosofia do autor, estando afinado, portanto, com ela. Louis Proal, imprimindo uma revista e uma visada num único movimento sob a íntegra agora do pensamento de Rousseau, expressa todo seu pasmo frente aos paradoxos e mesmo diante daquele quadro que, aos seus olhos, não passa de um mundo de incongruências e desconexões:

Faguet disse de Voltaire: é um caos de idéias claras. Pode-se dizer de Rousseau: é um caos de idéias eloqüentes contraditórias. Ele é sempre sincero, mas sobre um grande número de questões conserva opiniões diferentes; não diz senão aquilo que pensa, mas isso que ele pensa é seguidamente o contrário disso que escreve; ele tem opiniões sucessivas, diferentes, contraditórias. O Marquês de Mirabeau lhe escreveu: 'Vós sois sempre verdadeiro segundo vossa consciência momentânea'. Rousseau possui convicções ardentes, mas momentâneas. Poder-se-ia fazer um livro intitulado: Rousseau refutado por ele mesmo, dividindo cada página em duas colunas onde o pró e o contra seriam expostos. ${ }^{2}$

2 PROAL, L., La psychologie de Jean-Jacques Rousseau. Paris: Librairie Félix Alcan, 1930, p.292. 
Apesar desta linha de interpretação, a filosofia de Rousseau constituise como bem mostram, ilustrativamente falando, René Hubert e Ernst Cassirer, como um todo coerente e unívoco, que é coroado e assume seu sentido mais profundo com o Do contrato social, permitindo-nos dele falar, hoje, como uma obra que avança aquilo que tivemos um esboço no Primeiro e no Segundo Discurso.

Rousseau nas Confissões, precisamente no livro IX deste trabalho, que se constitui talvez num modelo de autobiografia filosófica, e em sua nota de advertência do Contrato, retrata a questão do significado para ele do texto em análise, tanto na relação com seu plano teórico em sentido amplo quanto com sua história concreta de vida. O filósofo genebrino acalentava o desejo, com efeito, de escrever um grande trabalho ao qual ele atribuiria o nome de Instituições políticas. Conservando incomparável predileção pelo projeto teórico que deveria resultar nessa produção, Rousseau nele aplicava bastante de suas forças e habilidades pensando em torná-lo realizado. O que ele nutria de expectativa com a publicação da obra em tela, a qual encontrou um estímulo inicial para sua redação com sua estada em Veneza que lhe permitiu notar a importâcia da política para a vida social, era concluir seu trajeto intelectual e ver consolidar-se por conseguinte seu reconhecimento público:

das várias obras que tinha na gaveta, aquela sobre a qual mais meditava, que mais gosto me dava e na qual quereria trabalhar a vida inteira e que devia, segundo eu achava, coroar minha reputação, eram minhas Institutions politiques. Havia treze ou quatorze anos que me tinha ocorrido a primeira idéia quando, estando em Veneza, tinha tido ocasiões de observar os defeitos daquele tão gabado governo. Desde então minhas vistas se haviam estendido muito no estudo histórico da moral. $^{3}$

${ }^{3}$ ROUSSEAU, J.-J. Les confessions. Oeuvres Complètes, v.1, Paris: Gallimard, 1959, (Bilbiotèque de la Pléiade), p.404. 
O Do contrato social, que traz como subtítulo, sugestivamente, "princípios do direito político", é um texto que veicula uma parcela do gênio criador de Rousseau. Essa não se identifica de fato na totalidade de seu extenso repertório que se beneficia das leituras que teria realizado, passando por vários livros e autores, no curso de seu desenvolvimento intelectual estabelecido de maneira autodidata. Sua publicação se deu em abril de 1762, ou seja, aconteceu algumas poucas semanas antes do também representativo Emílio ou Da educação. Ele se caracteriza, conforme a nota de advertência acima referida, como um fragmento daquela grande empresa que o pensador teve de suspender no curso dos acontecimentos. Isto porque ele faltou ao não pesar sua complexidade logo no começo do trajeto, tendo superestimado, pois, suas forças pessoais. "Este pequeno tratado - argumenta Rousseau - foi extraído duma obra mais extensa, outrora iniciada sem que houvesse consultado minhas forças e de há muito abandonada. Dos vários trechos que se podiam tomar ao que estava feito, este é o mais considerável e pareceu-me o menos indigno de ser oferecido ao público. O resto não mais existe”. 4

Excerto de um grande projeto não levado ao seu ponto conclusivo, o Contrato não deixa de ser, de forma alguma, um livro rico teoricamente, difícil de ser compreendido, e central na reflexão de Rousseau. Malgrado aquela polêmica desnecessária já que o próprio filósofo indica como sua obra deve ser apreendida e estudada ${ }^{5}$, o trabalho em questão constitui-se numa conseqüência e num prolongamento das idéias desenvolvidas tanto em outras esferas da filosofia de Rousseau como em outros de seus escritos, dentre os quais é merecedor de destaque, como já dissemos, o Discurso sobre a desigualdade.

Ultrapassando a idéia de efetuar um diagnóstico do processo de derrocada do ser humano, no Contrato social o filósofo esforça-se no sentido de colocar os problemas especulativos em outras bases, pensando em apresentar um caminho para contornar os males políticos e sociais, mesmo que nem todos os povos tenham condições de se redimir dos problemas instituídos. Conforme Rousseau, segundo Grimsley, "é necessário, se resulta possível,

\footnotetext{
${ }^{4}$ ROUSSEAU, J.-J. Du contrat social; ou principes du droit politique. Oeuvres Complètes, v.3, Paris: Gallimard, 1964a, (Bibliotèque de la Pléiade), p.349.

${ }^{5}$ Rousseau, ele mesmo, argumenta em prol da coerência e da unidade de sua obra como um todo, e desautoriza que seu leitor tome qualquer um de seus livros como algo absolutamente dissociado do conjunto de sua produção.
} 
ensinar o caminho da felicidade, ao menos para aquelas pessoas e nações - e talvez não hajam muitas - que todavía sejam capazes de perceberem e seguirem a verdade". ${ }^{6}$

Se o Discurso sobre a desigualdade permitiu concluir, em algum momento, que a preocupação de Rousseau era com problemas factuais ou históricos, embora ele não tenha almejado ocupar-se com isto, agora não resta dúvida de que toda sua perplexidade e inquietude está orientada para o campo dos fundamentos do direito político, mesmo que esses fundamentos tenham de indicar uma conexão da teoria com a prática. Eis os termos de Rousseau pelos quais é referendado esse nosso juízo: "quero indagar se pode existir, na ordem civil, alguma regra de administração legítima e segura, tomando os homens como são e as leis como podem ser. Esforçar-me-ei sempre, nessa procura, para unir o que o direito permite ao que o interesse prescreve, a fim de que não fiquem separadas a justiça e a utilidade". ${ }^{7}$

Ao observar os termos que a racionalização de Rousseau pretende articular, nota-se que sua meta maior reside em perguntar-se em relação a possibilidade de se estabelecer teoricamente um engenho jurídico-político cujo traço substantivo seja a legitimidade. Para chegar a esse objetivo, ele julgou necessário levar em conta, antes de qualquer coisa, os homens como eles efetivamente são e as leis como elas têm condições de ser no plano da ordem social e política. Essa empresa poderá se consolidar, atingindo os parâmetros positivos que se espera, desde que fique circunscrita, fixando-se no domínio civil, aos limites autorizados pelo direito, sem ultrapassar, pois, o âmbito reconhecidamente humano. Ao ver-se atendida essas exigências, darse-á o triunfo da justiça da qual, segundo o autor genebrino, haverá de advir a utilidade, diferentemente da idéia preconizada pelos sistemas utilitaristas, como, por exemplo, o da filosofia moral escocesa que, em razão da hierarquia conceitual estabelecida, vê estes termos combinados na ordem inversa. Quer dizer, eles, distanciando-se de Rousseau, julgam o útil como aquilo que é justo, consideram a legitimidade como puro reflexo da utilidade. Comentando Rousseau, João Lopes Alves argumenta:

\footnotetext{
${ }^{6}$ GRIMSLEY, R. La filosofía de Rousseau. Trad. de Josefina Rubio. Madrid: Alianza Editorial, 1993, p.27.

${ }^{7}$ ROUSSEAU, J.-J. Du contrat social. Oeuvres Complètes, v.3, Paris: Gallimard, 1964a (Bibliotèque de la Pléiade), p.351.
} 
enquanto, para os utilitaristas escoceses, e de um modo geral para todas as correntes de inspiração hedonista, o 'selfinterest' tende a funcionar como peça de charneira de um sistema de correspondência entre justiça e utilidade que permite qualificar como justo o que se mostra útil, Rousseau altera o sentido das correspondências ao postular que só a justiça pode ser social e individualmente útil. Não é o prazer do útil a fonte da justiça mas a justiça a fonte do prazer. ${ }^{8}$

Para encaminhar essa busca, Rousseau, após indicar que é um teórico e não um homem prático, e que por isto se dispõe a escrever sobre política, coloca a pergunta sobre qual o fundamento da ordem civil, ordem esta que dele recebe o designativo de "direito sagrado", haja vista ser de uma certa forma mais fundamental que os próprios indivíduos. Seu juízo introdutório, identificado no capítulo I do livro em análise, que será retomado nos desenvolvimentos posteriores, busca desfazer-se do pensamento que sustenta que as suas bases encontram-se assentadas na natureza pelo fato de considerar, tal como os demais filósofos jusnaturalistas, que ela é resultado unicamente de acordos estabelecidos entre os homens.

A investigação do Discurso sobre a desigualdade permitiu a Rousseau compreender que a ordem da natureza fez os homens livres e iguais. Muito embora não se tenha moralidade no estado de natureza, e o plano jurídico seja atingido com os convênios firmados entre as diferentes pessoas, a condição originária dos seres humanos é tomada como referência para definir a legitimidade destes atos. É a perplexidade de Rousseau com a ruptura da ordem natural que justifica o pasmo que termina revelando no início do livro I do Contrato social: "o homem nasce livre, e por toda a parte encontrase a ferros". Semelhante espanto nos faz lembrar daquelas reflexões desenvolvidas pelo filósofo nas últimas páginas do Discurso sobre a desigualdade.

Este panorama, como já sugerimos, seria produto da quebra com o ordenamento definido pelo supremo artífice e demonstra a perversidade dos homens bem como a incapacidade que eles possuem de seguir em seus retos

${ }^{8}$ ALVES, J. L. Rousseau, Hegel e Marx; percursos da razão política. Lisboa: Livros Horizontes, 1983 p.16.

${ }^{9}$ ROUSSEAU, J.-J. Du contrat social. Oeuvres Complètes. v.3, Paris: Gallimard, 1964a, (Bibliotèque de la Pléiade), p.351. 
caminhos. Em razão da ilegitimidade do convênio que lhe deu forma, a comunidade inteira surge acorrentada não se livrando desse mal nem sequer os seus proponentes que teriam sido, de acordo com o Segundo Discurso, justamente os ricos. Rousseau afirma pelo fim nas páginas do Contrato: "o que se crê senhor dos demais, não deixa de ser mais escravo do que eles". ${ }^{10}$

\section{II}

Considerando-se que uma pessoa se coloque a pergunta sobre a possibilidade de haver alguma instituição política advinda diretamente das mãos da natureza, não existe uma outra alternativa senão apontar a família como sendo esta suposta instituição. Devemos entender, porém, que a família constitui-se numa comunidade natural, na verdade, que subsiste apenas durante o período em que os filhos dependem de seus progenitores, tendendo a dissolver-se no momento em que eles conseguem andar com as próprias pernas. Quando essa permanece e consegue estender-se no tempo seria devido ao assentimento e ao desejo declarado de seus membros. Se as coisas acontecem desta forma, essa deixa de ser natural e torna-se efetivamente uma instituição política pois a concordância dos indivíduos é um requisito para ela assumir semelhante formato, quer dizer, para ela fazer-se uma associação política: "os filhos, isentos da obediência que devem ao pai, e este, isento dos cuidados que deve aos filhos, voltam todos a ser igualmente independentes. Se continuam unidos, já não é natural, mas voluntariamente, e a própria família só se mantém por convenção". ${ }^{11}$

$\mathrm{O}$ autor reconhece, preliminarmente, os direitos que envolvem a paternidade, os quais permitem a estipulação de condições para o encaminhamento da subsistência e do bem-estar dos filhos. Cogitar definir esses direitos como alicerces da ordem política é julgado pelo filósofo, no entanto, como uma coisa inconveniente visto que a existência destes termina quando a prole alcança a idade da razão. Alienar a liberdade diante da presença da autoridade paterna grosso modo justifica-se, aos olhos de Rousseau, durante o tempo em que é impossível aos filhos gozarem de verdadeira autonomia. E esse ato de subordinação, para manter-se como algo legítimo, precisa obedecer inexo-

\footnotetext{
${ }^{10}$ ROUSSEAU, J.-J. Du contrat social. Oeuvres Complètes. v.3, Paris: Gallimard, 1964a, (Bibliotèque de la Pléiade), p.352.

${ }^{11}$ ROUSSEAU, J.-J. Du contrat social. Oeuvres Complètes. v.3, Paris: Gallimard, 1964a, (Bibliotèque de la Pléiade), p.352.
} 
ravelmente ao princípio da entrega individual apenas em vistas do proveito extraído por semelhante agente. Havendo obediência a essa regra, não se verifica uma conduta passível de ser julgada uma transgressão frente aos imperativos da natureza.

Seguindo na busca do fundamento do direito político, e permanecendo conivente com a idéia de que este não pode alimentar-se ou estar ancorado num poder de cunho arbitrário, Rousseau passa a refutar o pensamento de Aristóteles. Abrindo-se os capítulos iniciais do livro I de $A$ política, vê-se o autor antigo justificar que existe, em virtude da ação interventiva da natureza, uma desigualdade moral e política entre os homens, a qual ele ilustra valendo-se, notadamente, da figura do senhor e do escravo. Observemos seu juízo extraído do capítulo II que referenda sua concepção substantivamente aristocrática:

há também por obra da natureza e para a conservação das espécies, um ser que ordena e um ser que obedece. Porque aquele que possui inteligência capaz de previsão tem naturalmente autoridade e poder de chefe; o que mais possui além da força física para executar, deve, forçosamente, obedecer e servir - e, pois, o interesse do senhor é o mesmo que o do escravo. ${ }^{12}$

Esse mesmo argumento que define a desigualdade entre os homens como algo natural aparece no capítulo II com o acréscimo da idéia de que o exercício da autoridade se legitima, alcançando grande estatura, quando aquele que a exerce é talhado para a função: "alguns seres, ao nascer, se vêem destinados a obedecer; outros, a mandar. E formam, uns e outros, numerosas espécies. A autoridade é tanto mais alta quanto mais perfeitos são os que a ela se submetem". 13

Aristóteles fecha esse tópico em questão colocando em par de igualdade o estrangeiro, a pessoa do sexo feminino, e o escravo. Nivelando-os por baixo, ele os toma em conjunto como seres humanos fadados, inapelavelmente, a subsistirem em estado de clara subordinação.

12 ARISTÓTELES. La politique, 1252a 5. Paris: Vrin, 1970, (Bibliotèque des Textes Philosophiques), p.24.

${ }_{13}$ ARISTÓTELES. La politique, 1254a 8. Paris: Vrin, 1970, (Bibliotèque des Textes Philosophiques), p.29. 
Entre os bárbaros a mulher e o escravo se confundem na mesma classe. Isso acontece pelo fato de não lhes ter dado a natureza o instinto de mando, e de ser a união conjugal a de uma escrava com um senhor. Falaram os poetas: 'os gregos têm o direito de mandar nos bárbaros' como se a natureza distinguisse o bárbaro do escravo. ${ }^{14}$

Dado ao fato de jugar, nessa passagem, ser esta realidade determinada pela natureza, o filósofo grego reflete uma mentalidade própria de seu meio político e social, suscitando-nos o pensamento de que há uma inclinação tirânica da cultura helênica, justificada no próprio âmbito especulativo.

Rousseau sustenta, no intuito de combater a tese do filósofo de Estagira, que ele tomou o efeito pela causa, esquecendo-se de lembrar que foi a força a instituidora deste panorama díspare. $\mathrm{Na}$ opinião do pensador genebrino: "se há, pois, escravos pela natureza, é porque houve escravos contra a natureza. A força fez os primeiros escravos, sua covardia os perpetuou". ${ }^{15}$

Se Rousseau havia afirmado, logo no começo de sua reflexão, que a legitimidade do poder não poderia estar ancorada na autoridade paterna, presentemente ele avança dizendo, pois, não deitar suas raízes também na força. Costuma-se respeitar essa última, segundo ele, por uma questão de necessidade e de prudência, mas cada um de nós se encontra livre para desprezá-la desde que tenha a certeza de que a subsistência individual está plenamente assegurada. A partir desse momento não existe mais razão para ver a força como fonte de poder ou como instrumento legítimo de coação.

Servindo os contratos estabelecidos entre os homens como base da autoridade política legítima, seria equivocado considerar-se como tal aquela que busca consagrar os efeitos da violência. A lei da natureza bem como o direito natural não autoriza que o poder se revista desta maneira fazendo-se arbitrário quando almeja instituir-se enquanto algo de direito: "homem algum tem autoridade natural sobre seus semelhantes e [...] a força não produz qualquer direito, [...] restam as convenções como base de toda a autoridade legítima existente entre os homens". ${ }^{16}$

${ }^{14}$ ARISTÓTELES. La politique, 1252b 5-6. Paris: Vrin , 1970, (Bibliotèque des Textes Philosophiques), p.24.

${ }^{15}$ ROUSSEAU, J.-J. Du contrat social. Oeuvres Complètes, v.3, Paris: Gallimard, 1964a, (Bibliotèque de la Pléiade), p.353.

${ }^{16}$ ROUSSEAU, J.-J. Du contrat social. Oeuvres Complètes, v.3, Paris: Gallimard, 1964a, (Bibliotèque de la Pléiade), p.355. 
Todo o acordo firmado entre os seres humanos, se quiser assumir o caráter de legitimidade e assegurar-se na posição de sustentáculo do direito, deve atender, no julgamento de Rousseau, aos interesses de todas as partes contratantes. Esses interesses, afastados dos esforços coativos e arbitrários, pulsam em sintonia com os ditames do direito natural que clamam pela liberdade e pela igualdade. Seria aceitável aos olhos do filósofo, que um indivíduo, vendo-se forçado a alienar sua vontade, se entregasse, por conseguinte, nas mãos de outro semelhante em função do desejo de garantir sua integridade e sua subsistência. Identificar-se-ia, nesse caso, uma motivação muito razoável que anunciaria uma expectativa concreta de ganho pessoal. Somente um interesse determinado, como é o caso aí do anseio de assegurar a sobrevivência, pode levar um homem a agir desta forma, pois será contrário à natureza dar-se gratuitamente, entregar-se de forma incondicional. Rousseau considera que a liberdade constitui-se, em síntese, na essência do ser humano e abriga a fonte de toda sua dignidade:

renunciar à liberdade é renunciar à qualidade de homem, aos direitos da humanidade, e até aos próprios deveres. Não há recompensa possível para quem a tudo renuncia. Tal renúncia não se compadece com a natureza do homem, e destituir-se voluntariamente de toda e qualquer liberdade equivale a excluir a moralidade de suas ações. ${ }^{17}$

Rousseau estabelece o princípio de que não há como deixar de considerar-se nulo todo o convênio que estipula a presença de uma autoridade irrestrita face a uma submissão individual absoluta. $\mathrm{E}$ isso é verdadeiro mesmo que se possa admitir com a leitura de seus textos, em algum momento, que a vida seja um bem superior ao fato de gozar-se de liberdade. Essa compreensão do filósofo neutraliza a possibilidade de se identificar as bases legítimas do poder político, portanto, na entrega de um escravo ao seu senhor ou na inteira subordinação de um povo vencido na guerra. Se inexiste legitimidade, em primeiro lugar, na relação entre um senhor e um escravo, os direitos em que se envolve o evento da guerra, em segundo lugar, restringemse absolutamente ao fim a que ela se presta, tendendo a vigorar durante o tempo em que se apresenta em atividade como um acontecimento:

${ }_{17}$ ROUSSEAU, J.-J. Du contrat social. Oeuvres Complètes, v.3, Paris: Gallimard, 1964a, (Bibliotèque de la Pléiade), p.356. 
estando o fim da guerra na destruição do Estado inimigo, tem-se o direito de matar, no seu curso, os defensores enquanto estiverem de armas na mão; no momento, porém, em que as depõem e se rendem, deixando de ser inimigos ou seus instrumentos, tornam-se simplesmente homens, não mais se tendo direito à sua vida. Algumas vezes, pode-se eliminar o Estado sem matar um único de seus membros; ora, a guerra não concede nenhum direito que não os necessários à sua finalidade. ${ }^{18}$

Se considerarmos que a busca da autopreservação constitui-se num princípio da natureza humana é aceitável conceber que se possa destruir o inimigo num conflito bélico. Mas surge daí a dúvida em razão dos imperativos do direito natural uma vez que estes sustentam ser tanto a vida quanto a liberdade coisas absolutamente inalienáveis de um modo incondicional. Rousseau admite no entanto, como já observamos, que se fica livre para matar o inimigo numa guerra caso não seja possível escravizá-lo. Ele considera, porém, que a guerra, assim como a relação entre senhor e escravo, encontra-se subordinada ao princípio da lei do mais forte, não podendo, pois, ser elevada ao plano do direito. "Um escravo feito na guerra ou um povo dominado não tem qualquer obrigação para com seu senhor, senão obedecê-lo enquanto a isso é forçado". ${ }^{19} \mathrm{O}$ fato mesmo está, em resumo, na nulidade da correspondência, para Rousseau, entre escravidão e direito, assim como a força, por outro lado, não possui verdadeiro poder, na concepção do autor, para legitimar qualquer convênio, estando impedida, portanto, de servir-lhe de fundamento.

\section{III}

A argumentação do capítulo V do livro I do Contrato social, com efeito, é estratégica para compreender-se o raciocínio de Rousseau no tocante ao problema focalizado no presente momento. Reparando o juízo de Grotius, o filósofo convida o leitor a pensar que antes do pacto de submissão houve um outro convênio pelo qual se viu o povo fazer-se povo, residindo

${ }^{18}$ ROUSSEAU, J.-J. Du contrat social. Oeuvres Complètes, v.3, Paris: Gallimard, 1964a, (Bibliotèque de la Pléiade), p.358.

${ }^{19}$ ROUSSEAU, J.-J. Du contrat social. Oeuvres Complètes, v.3, Paris: Gallimard, 1964a, (Bibliotèque de la Pléiade), p.358. 
neste acordo, por conseguinte, as bases do direito político: "antes, pois, de examinar o ato pelo qual um povo elege um rei, conviria examinar o ato pelo qual um povo é povo, pois esse ato, sendo necessariamente anterior ao outro, constitui o verdadeiro fundamento da sociedade". ${ }^{20}$ Essa assertiva encontra sentido no fato de Rousseau entender que o corpo político, mantendo legitimidade no plano do poder, resulta de um pacto que representa uma ação moral, uma deliberação pública consciente. Semelhante ato envolve o reconhecimento da vontade, então, da parte de cada um dos membros do acordo, supondo-se a unanimidade dos sufrágios naquele ponto de origem.

Essa pressuposição acima facilita o trabalho, sobretudo, de buscar-se entender as refinadas construções teóricas rousseaunianas, organizadas na perspectiva do dever ser da política. Semelhantes elaborações intelectivas e filosóficas aparecem expostas nos capítulos VI e VII do texto em análise que podem ser considerados talvez seus momentos mais nevrálgicos e substantivos.

É importante termos certo que o Contrato não surge como um programa de ação, deixando de significar, pois, algo que deve ser executado em termos práticos. Seu móvel reside apenas numa espécie de experiência com os princípios articulados no escrito, valendo-se da referência a um certo sistema de medidas que assume o caráter de modelo. Isso não foi bem interpretado, entretanto, no transcurso da história da filosofia moderna e contemporânea. Daí o juízo que segue, formulado pelo professor Milton Meira do Nascimento:

nas anotações à margem do "Contrato social", Voltaire deixará claro novamente que espera de Rousseau alguma coisa que vá modificar diretamente a vida política, um programa político, quando não considera a distinção fundamental que Rousseau faz entre soberania e governo [...]. A partir daí, surgirá uma linha interpretativa do "Contrato social" sempre no sentido de tomá-lo como um programa para a ação política. Essa tradição é reforçada pelos revolucionários de 1789 , reafirmada

${ }^{20}$ ROUSSEAU, J.-J. Du contrat social. Oeuvres Complètes, v.3, Paris: Gallimard, 1964a, (Bibliotèque de la Pléiade), p.359. 
por Proudhon e muitos outros no século seguinte, e chega até os nossos dias. ${ }^{21}$

Aparece sintetizado no começo do capítulo VI do Contrato social, todavia, os elementos teóricos com os quais se envolveu toda a etapa inicial da reflexão do Discurso sobre a desigualdade, mesmo que um livro se prenda ao direito e o outro transite para o campo dos fatos ou da história hipotética. Aí o filósofo genebrino parte do princípio de que os homens, ao abandonarem sua condição verdadeiramente natural, ao deixarem seu estado de fato primitivo, terminaram atingindo, tanto em razão da ação do tempo como pela influência do desenvolvimento histórico, um nível insuportável de conflitos na esfera das relações interpessoais. Diante disso, perante o caos instituído, fez-se necessário propor e encaminhar o pacto social com a finalidade de estabelecer-se a sociedade política visto que esta era a única forma de neutralizar todos os problemas.

suponhamos os homens chegando àquele ponto em que os obstáculos prejudiciais à sua conservação no estado de natureza sobrepujam, pela sua resistência, as forças de que cada indivíduo dispõe para manter-se nesse estado. Então, esse estado primitivo já não pode subsistir, e o gênero humano, se não mudasse de modo de vida, pereceria. ${ }^{22}$

Os homens vivem nesse quadro disforme, afastado de sua condição primeira que se caracterizaria também por contar com algo de positivo, numa condição de miserabilidade porque suas forças individuais não lhes bastam sendo insuficientes para preservá-los. ${ }^{23}$ Antes dessa situação lamentável, eles mantinham-se de fato limitados e gozavam de uma liberdade de caráter natural. Torna-se necessário ver-se realizada, porém, a verdadeira destinação do ser humano com a qual ele haverá de alcançar uma liberdade de

${ }^{21}$ NASCIMENTO, M. M. . "O contrato social; entre a escala e o programa". Revista Discurso, no 17 , 1988. p.123.

22 ROUSSEAU, J.-J. Du contrat social. Oeuvres Complètes, v.3, Paris: Gallimard, 1964a, (Bibliotèque de la Pléiade), p.360.

${ }^{23}$ Para ampliar a reflexão sobre esse tópico consultar: BOBBIO, N. "El modelo jusnaturalista". In.: BOBBIO, N.; BOVERO, M. Soiedad y estado en la filosofía moderna. Trad. de José Santillán. México: Fondo de Cultura Económica, 1986, p.79-81. 
tipo superior, isto é, a liberdade convencional que o transformara em senhor de si mesmo.

Toda a expectativa volta-se ao desafio de empreender-se o pacto social legítimo que aparece como o evento que irá possibilitar a inauguração da sociedade de direito. Com esse acontecimento histórico, dar-se-ia a ultrapassagem do grande dilema da vida política, que consiste em conjugar, segundo Salinas Fortes, vontade particular e vontade coletiva no plano público atendendo às exigências estabelecidas pela lei natural: "os homens necessitam uns dos outros: eis o ponto de partida. Como uni-los mantendo-os ao mesmo tempo livres? Eis a aporia da vida coletiva, eis o grande paradoxo de toda a política" ${ }^{24}$

O pacto social que é projetado envolve um interesse realmente público e por isso exige que se descubra uma forma de ampliar-se as forças humanas individuais que se fazem no momento, como já dissemos, um tanto precárias. Como uma pessoa é impotente para aumentá-la na medida necessária permanecendo isolada, mantendo-se independente, não sobra outra alternativa senão efetivar-se uma soma de todas as forças, transferindo o poder de decisão para a esfera pública. Semelhante operação é viabilizada com o pacto que transforma cada contratante num agente político que encontra o privilégio de reconhecer-se ali na dimensão coletiva dada à afluência de sua vontade.

Segundo Rousseau, aquilo que se obtém, em síntese, é o corpo político ideal que cria uma força comum e supera o entrave tanto de unir os homens, sem privá-los de sua liberdade, como vence o obstáculo de garantir seus bens materiais, ainda que haja a presença do Estado. Todo o desafio consiste, enfim, justamente nisso: "encontrar uma forma de associação que defenda e proteja a pessoa e os bens de cada associado com a força comum, e pela qual cada um, unindo-se a todos, só obedece contudo a si mesmo, permanecendo tão livre quanto antes" ${ }^{25}$

Primazial no interior deste ato associativo ora pensado, que deverá trazer a solução de um dilema, é a necessidade inexorável de haver a alienação completa dos participantes do convênio, com todos os seus direitos em prol do grupo em seu conjunto. A obediência e a observância desse imperativo viabiliza a conquista da autonomia individual, torna familiar o modo de

${ }^{24}$ FORTES, L. R. S. "O mundo político como vontade e representação". Revista Filosofia Política 2. Porto Alegre: L\&PM, 1985, p.93.

${ }^{25}$ ROUSSEAU, J.-J. Du contrat social. Oeuvres Complètes, v.3, Paris: Gallimard, 1964a, (Bibliotèque de la Pléiade), p.360. 
sociabilidade que seria irretocável, e garante os seres humanos distantes do tipo de vida desfrutada nos tempos que o antecederam. Os termos seguintes de Rousseau, presos à cláusula essencial do pacto, revelam ser este ato de alienação o núcleo central de sua formulação teórica mais engenhosa. Com essa formulação o autor resolve um problema filosófico difícil e importante, antecipando, assim, as teorizações de Kant, desenvolvidas ainda no século XVIII, quando o pensador alemão discute a questão da liberdade:

essas cláusulas bem compreendidas reduzem-se todas a uma só: a alienação total de cada associado, com todos os seus direitos, à comunidade toda, porque, em primeiro lugar, cada um dando-se completamente, a condição é igual para todos, e, sendo a condição igual para todos, ninguém se interessa por torná-la onerosa para os demais. ${ }^{26}$

Simbolizando um elemento fundamental para a legitimidade da ordem política, o pacto de associação define um quadro de perfeita unidade no plano da vida social em função de acontecer uma entrega sem reservas que produz a estruturação de um corpo moral e coletivo. Ninguém permanece, neste caso, subordinado a nenhum particular, ganha-se o equivalente do que se perde, e fica-se com mais forças para conservar o que se possui, representando, conseqüentemente, uma troca justa. "Enfim, cada um dando-se a todos não se dá a ninguém e, não existindo um associado sobre o qual não se adquira o mesmo direito que se lhe cede sobre si mesmo, ganha-se o equivalente de tudo que se perde, e maior força para conservar o que se tem". ${ }^{27}$

Temos o surgimento aqui, em linhas gerais, de uma pessoa pública a qual é conhecida hoje como corpo político ou república. Esse corpo é colocado em atividade graças à presença do soberano, isto é, do povo em seu conjunto, que assumiu este posto de senhor absoluto, sob o ponto de vista

${ }^{26}$ ROUSSEAU, J.-J. Du contrat social. Oeuvres Complètes, v.3, Paris: Gallimard, 1964a, (Bibliotèque de la Pléiade), p.360-361. "Como conciliar igualmente a liberdade de todos com as necessidades da vida coletiva, com as vicissitudes da convivência tornada indispensável e inevitavelmente restritiva da independência natural? A genial solução teórica encontrada por Rousseau, numa antecipação da autonomia kantiana, está justamente na noção de soberania da vontade geral. Ou seja, na alienação total de cada associado com todos os seus direitos a toda a comunidade, segundo enuncia lapidarmente a cláusula do pacto social"(FORTES, Luis Roberto Salinas. "O mundo político como vontade e representação". Revista Filosofia Política 2. Porto Alegre: L \& PM, 1985, p.93).

${ }^{27}$ ROUSSEAU, J.-J. Du contrat social. Oeuvres Complètes, v.3, Paris: Gallimard, 1964a, (Bibliotèque de la Pléiade), p.361. 
do poder, com a realização do pacto, que coloca o governo numa posição subordinada. Cada homem, julgado em separado, visto como simples indivíduo, enquanto aparece como um membro ativo no interior do domínio é definido como cidadão. Agora quando esse mesmo indivíduo submete-se às leis do Estado, ele torna-se súdito e representa, por conseguinte, o corpo político enquanto ser passivo.

É fundamental ter-se clareza, contudo, de que o pacto, desde o momento em que é realizado, cria um tipo de compromisso entre os contratantes que ofender, de uma parte, um de seus membros representa atingir o corpo por completo, o organismo em seu conjunto, devido à unidade aí existente. Mas, se pensarmos numa investida pessoal ou conjunta de um partido ou de um grupo isolado e belicoso em direção a esse corpo político maior com o objetivo de desestabilizá-lo a conseqüência não haverá de ser diferente:

cada indivíduo, contratando, por assim dizer, consigo mesmo, se compromete numa dupla relação: como membro do soberano em relação aos particulares, e como membro do Estado em relação ao soberano [...]. Desde o momento em que essa multidão se encontra assim reunida em um corpo, não se pode ofender um dos membros sem atacar o corpo, nem, ainda menos, ofender o corpo sem que os membros se ressintam. ${ }^{28}$

O soberano, significando o povo em seu conjunto, possui o desígnio de expressar a vontade geral, vontade esta para a qual fica atribuída a incumbência de formalizar o conjunto de regras diretivas que deverão assumir-se enquanto sua expressão manifesta. Com a intervenção dessa vontade, vê-se assegurado, inexoravelmente, o interesse de toda comunidade, pois ela tende sempre para a utilidade pública, diferentemente do que acontece com a vontade particular. Constituindo-se no fator que garante a preservação da sociedade de direito, a vontade geral termina se transformando em princípio supremo. "Só a vontade geral pode dirigir as forças do Estado de acordo com a finalidade de sua instituição, que é o bem comum". ${ }^{29} \mathrm{O}$ ato de associação

${ }^{28}$ ROUSSEAU, J.-J. Du contrat social. Oeuvres Complètes, v.3, Paris: Gallimard, 1964a, (Bibliotèque de la Pléiade), p.362-363.

${ }^{29}$ ROUSSEAU, J.-J. Du contrat social. Oeuvres Complètes, v.3, Paris: Gallimard, 1964a, (Bibliotèque de la Pléiade) p.368. 
empreendido, sendo marcado pelo traço de legitimidade, torna forçoso enfim obedecê-la, porquanto da vontade geral depende a liberdade humana mais elevada, isto é, a liberdade convencional. Dessa forma: "aquele que recusar a vontade geral a tanto será constrangido por todo um corpo, o que não significa senão que o forçarão a ser livre". ${ }^{30}$

O ser humano aos olhos de Rousseau, contudo, beneficia-se muito com o pacto legítimo e com a passagem para o estado de direito. Assumindo uma outra leitura sobre o sentido da vida em sociedade, ele não leva mais em conta apenas seus interesses pessoais. Guiando-se pelos ditames de seu sentimento interior e pelas vozes da razão, superando, dessa maneira, sua condição de presa absoluta dos instintos, neutraliza seus impulsos egoístas, predispondo-se a considerar só os apelos do dever. Fechado em relação às prescrições advindas do mundo externo, alcança a liberdade moral e torna-se, assim, um ser autônomo, senhor de seus atos, passando a obedecer apenas à lei que prescreve para si mesmo na qualidade de membro da associação política. Conforme o filósofo, esta espécie de liberdade, adquirida por esse trabalho que propicia a desnaturação do ser humano em seu sentido positivo, elevando-o na escala de existência de seu próprio gênero, seria a "única a tornar o homem verdadeiramente senhor de si mesmo, porque o impulso do puro apetite é escravidão, e a obediência à lei que se estatuiu a si mesmo é liberdade". 31

O ganho do ser humano com o pacto legítimo, entretanto, não reside apenas em deixar de gozar de sua mera independência natural ou de se afas$\operatorname{tar}$ da condição servil estabelecida artificialmente com o acordo ilegítimo proposto pelos ricos. É conquistada também a igualdade convencional que subtrai, pelo fim, o peso das diferenças naturais que, embora sejam existentes, exercem para Rousseau influência reduzida no estado de natureza.

\footnotetext{
${ }^{30}$ ROUSSEAU, J.-J. Du contrat social. Oeuvres Complètes, v.3, Paris: Gallimard, 1964a, (Bibliotèque de la Pléiade), p.364.

${ }^{31}$ ROUSSEAU, J.-J. Du contrat social. Oeuvres Complètes, v.3, Paris: Gallimard, 1964a, (Bibliotèque de la Pléiade), p.365.
} 


\section{IV}

A instituição política, o corpo moral e coletivo, que resulta do pacto social legítimo, com efeito, não seria uma coisa alheia ao indivíduo uma vez que ele representa sua base, significa seu fundamento. Isso é algo que não foi compreendido, desde o século XIX, por muitos intérpretes do pensamento de Rousseau. Esse seria o caso, por exemplo, de Benjamin Constant que em seu famoso escrito de 1818, no qual trata da questão da liberdade dos antigos comparada à dos modernos, considera que o pensador genebrino, apesar de manter em seu íntimo um amor profundo à liberdade, pensa esta última nos moldes da filosofia disseminada no mundo antigo. Para Constant, a liberdade dos modernos advém da segurança nas fruições privadas, sendo uma tal espécie de liberdade algo que está fundado plenamente no espírito desta época. É ponto pacífico, na opinião do autor, a necessidade de manter, nos tempos atuais, a autonomia política e conservar-se a segurança dos indivíduos uma vez que o essencial reside no zelo das regalias de usufruto dos particulares. Em suma: "não se deve [...] pedir seu sacrifício (sacrifício da liberdade subjetiva) para estabelecer a liberdade política". ${ }^{32}$

O escritor francês do século XIX reconhece o dilema que são convidados a enfrentar os Estados Contemporâneos mais desenvolvidos econômica e socialmente pelo qual se definem duas exigências básicas, a saber, a necessidade por um lado de limitar o poder político, mas, por outro, o valor de saber distribuí-lo ao mesmo tempo adequadamente. Ele é certo, entretanto, que "não podemos mais usufruir da liberdade dos antigos, que era constituída pela participação ativa e constante no poder coletivo". ${ }^{33}$

Constant ressalta, parafraseando Condorcet, que os antigos ignoravam a noção dos direitos individuais e assemelhavam-se a máquinas em que a lei regulava as molas e dirigia as engrenagens. Em seu entender, Rousseau comunga, com sua teoria apresentada no Contrato social, com um tipo de liberdade tal qual os homens dos tempos antigos abertamente preservavam. Ele cumpre, dessa forma, um papel intelectual negativo, construindo, para Constant, um discurso essencialmente extemporâneo. "J.-J. Rousseau [...]

32 CONSTANT, B. De la liberté des anciens comparée a celle des modernes. Paris: Librairie Guillaumin, 1872, p.552.

${ }^{33}$ CONSTANT, B. De la liberté des anciens comparée a celle des modernes. Paris: Librairie Guillaumin, 1872, p.547. 
transportando para os tempos modernos um volume de poder social, de soberania coletiva que pertencia a outros séculos, este gênio sublime, que era animado pelo amor mais puro à liberdade, forneceu, todavia, desastrosos pretextos a mais de um tipo de tirania”. ${ }^{34}$ Benjamin Constant, no seu escrito em análise, se recusa a concordar com Rousseau em algum ponto, pois sua leitura é de que o filósofo genebrino preconiza, explicitamente, uma intervenção na liberdade subjetiva. Isto acontece quando ele expõe, em síntese, as fórmulas do pacto social legítimo pelas quais a autoridade do corpo social termina colocada, segundo o autor, no lugar hegemônico que caberia se reservar ao sujeito e sua respectiva liberdade que o acompanha e o dignifica.

Essa idéia de que há uma prefiguração, em Rousseau, da recusa da liberdade individual a partir de sua formulação teórica, como é sustentado por esse autor francês, recebe crédito, como havíamos indicado, na escrita de muitos outros leitores do filósofo genebrino que seguiram nesta mesma linha interpretativa. C.E.Vaughan e J.L.Talmon, por exemplo, chegam praticamente a mesma conclusão estabelecida por Constant. Vaughan, esse importante editor de um conjunto de obras políticas de nosso filósofo, sustenta que ele aspirou inicialmente garantir a liberdade civil aos indivíduos formulando seus princípios teóricos, mas terminou desembocando numa espécie de justificação de uma forma radical e exagerada de coletivismo. No entender de Vaughan:

há divergência e mesmo contradição entre as hipóteses iniciais de Rousseau e as conclusões de seu livro. Rousseau parte primitivamente do individualismo de Locke para chegar finalmente a uma concepção radicalmente oposta, a 'uma forma extrema de coletivismo'. O que Rousseau se propõe a fazer é incorporar o indivíduo a cidade e absorvê-lo no Estado à maneira de Platão. ${ }^{35}$

Não isolamos as fortes controvérsias existentes em torno da teoria política de Rousseau ao afirmar que o Do contrato social traz preceitos mal construídos e que ele foi julgado pelo filósofo como deficitário e incompleto,

${ }^{34}$ CONSTANT, B. De la liberté des anciens comparée a celle des modernes. Paris: Librairie Guillaumin, 1872 , p.549.

35 VAUGHAN, C. E. "Introduction: Rousseau as political philosopher". In.: ROUSSEAU, Jean-Jacques. The Political Writing oj Jean-Jacques Rousseau. ed. C.E. Vaughan. Oxford, Basil Blackwell, v.1, 1962, p.70-71. 
sendo merecedor de uma reformulação caso ele tivesse fôlego e condições para fazê-la. Mas compete a nós dizer, neste momento, que esta revelação chegou a ser feita por Rousseau a um amigo: "quanto ao meu contrato social os que se vangloriam de o entender por inteiro são mais hábeis do que eu; trata-se de um livro a ser refeito. Porém, eu não tenho mais nem força e nem tempo". ${ }^{36}$

Ao realizar-se uma análise interna do pensamento de Rousseau, podese observar, contudo, que sua concepção de liberdade em nada parece com a que lhe atribui Benjamin Constant e mesmo aqueles que, mostrando-se sintonizados com a perspectiva do pensamento político liberal, seguem em sua mesma linha de leitura. Para o filósofo genebrino, a liberdade suprema não reside no arbítrio ou no mero capricho acidental que nos remete àquela fruição própria do homem fora do Estado, mas se atinge por intermédio da lei que cada indivíduo prescreve a si mesmo na qualidade de membro da associação política. Ele considera que toda a lei verdadeira é liberdade, e a crítica de Constant é realizada em função de que esta última, com a articulação de nosso autor, se prenderia à projeção da instituição política, e não a uma iniciativa individual que concederia ao sujeito, aliás, tanto a segurança quanto a liberdade. $\mathrm{O}$ equívoco de Constant reside, ao nosso ver, no fato de ele esquecer-se de pensar que essa instituição política não é, como já dissemos, alheia ao indivíduo, uma vez que ele constitui-se em sua base, em seu fundamento. Em suma, a despeito da idéia cultivada pelo intelectual e parlamentar francês, os contratantes não surgem, de um lado, como rivais da comunidade, e muito menos ficam postos à sua margem, pois são eles efetivamente que a constituem. Se as suas bases estão ancoradas no compromisso entre os cidadãos, este dito compromisso, de outro lado, é finalmente um compromisso do cidadão consigo mesmo.

${ }^{36}$ DUSAULX apud JULLIARD, Jacques. La faute à Rousseau. Paris: Édtions du Seuil, 1985, p.18. 


\section{Referências bibliográficas}

ALVES, J. L. Rousseau, Hegel e Marx, percursos da razão política. Lisboa: Livros Horizonte, 1983.

ARISTÓTELES. Politics. With an English Translation by H. Rackham. Cambridge, Massachusetts, London, England, Harvard: University Press, 1998.

BOBBIO, N.; BOVERO, M. Sociedad y estado en la filosofia moderna. Trad. de José Santillán. México: Fondo de Cultura Económica, 1986.

CONSTANT, B. De la liberté des anciens comparée a celle des modernes. Paris: Librairie Guillaumin, 1872.

DURKHEIM, É. Montesquieu et Rousseau; précurseurs de la sociologie. Paris: Librairie Marcel Rivière et Cie, 1953.

FORTES, L. R. S. "Rousseau; o mundo político como vontade e representação. Revista Filosofia Política 2. Porto Alegre: L\&PM, 1985.

GRIMSLEY, R. La filosofia de Rousseau. Trad. de Josefina Rubio. Madrid: Alianza Editorial, 1993.

JULLIARD, J. La faute à Rousseau. Paris: Éditions du Seuil, 1985.

NASCIMENTO, M. M. "O Contrato social; entre a escala e o programa". Revista Discurso, $\mathrm{n}^{\mathrm{a}}$ 02, 1984.

PROAL, L. La psychologie de Jean-Jacques Rousseau. Paris: Librairie Félix Alcan, 1930.

ROUSSEAU, J.J. Les confessions. Oeuvres Complètes, v.1, Paris: Gallimard, 1959, (Bibliotèque de la Pléiade).

Du contrat social. Oeuvres Complètes, v.3, Paris: Gallimard, 1964a, (Bibliotèque de la Pléaide).

Discours sur l'origine et les fondement de l'inégalité parmi les hommes. Oeuvres Complètes, v.3, Paris: Gallimard, 1964b, (Bibliotèque de la Pléiade).

VAUGHAN, C. E. "Introductions: Rousseau as political philosopher". in.: ROUSSEAU, Jean-Jacques. The political writings of Jean Jacques Rousseau. ed. C.E. Vaughan. Oxford, Basil Blackwell, 1962, 2 Vol.

E-mail: earlei@sercomtel.com.br

Recebido: $10 / 2008$

Aprovado: $11 / 08$ 